\title{
Effects Different Levels of Nanoparticles Chromium Picolinate Supplementation on Growth Performance, Mineral Retention, and Immune Responses in Broiler Chickens
}

\author{
Nattapon Sirirat ${ }^{1}$, Jin-Jenn Lu ${ }^{1}$, Alex Tsung-Yu Hung ${ }^{1}$, Shih-Yi Chen ${ }^{1} \&$ Tu-Fa Lien ${ }^{1}$ \\ ${ }^{1}$ Department of Animal Science, National Chiayi University, Taiwan, R.O.C. \\ Correspondence: Tu-Fa Lien, Department of Animal Science, National Chiayi University, Taiwan, R.O.C. Tel: \\ 886-5-2717536. E-mail: tflien@mail.ncyu.edu.tw
}

Received: August 23, 2012 Accepted: September 24, 2012 Online Published: November 15, 2012

doi:10.5539/jas.v4n12p48～URL: http://dx.doi.org/10.5539/jas.v4n12p48

\begin{abstract}
This study was conducted to investigate the effects of different levels nanoparticles of chromium picolinate (NanoCrPic) on the performance, immune responses, mineral retention, and tissues accumulation of chickens. A total of 180 broilers were randomly allocated into 0 (control), $500 \mathrm{ppb}\left(\mu \mathrm{g} \mathrm{kg}^{-1}\right) \mathrm{Cr}$ and $3000 \mathrm{ppb} \mathrm{Cr}$ groups with 6 replicates (10 birds/pen) for a 35-day experiment, the $\mathrm{Cr}$ is nanoparticles of chromium picolinate (NanoCrPic). In addition, 36 birds were used for metabolic experimental investigation. The results of the experimentation indicated that there were no significant differences in average body weight gain between groups, but feed conversion ratio (FCR) in 3000 ppb group was better than control group during 1-21 days. The carcass yields slightly lower in $3000 \mathrm{ppb}$ group than control $(\mathrm{p}<0.1)$. Retention ratio of $\mathrm{Zn}, \mathrm{Fe}, \mathrm{Mn}, \mathrm{Ca}$, and $\mathrm{P}$ were significantly $(\mathrm{p}<0.05)$ increased in the $500 \mathrm{ppb} \mathrm{Cr}$ group. The addition of NanoCrPic caused increased mineral concentrations, such as $\mathrm{Cr}, \mathrm{Ca}$ and $\mathrm{P}$ in the subjects' livers. Furthermore, the addition of NanoCrPic significantly increased lymphocytes and decreased both heterophils and $\mathrm{H} / \mathrm{L}$ ratio $(\mathrm{p}<0.05)$. The ND (Newcastle disease) antibody titer was not affected in the broilers. In conclusion, supplemental NanoCrPic improved the retention of $\mathrm{Zn}, \mathrm{Fe} \mathrm{Ca}$, notably it increased the concentration of $\mathrm{Cr}$ and $\mathrm{Ca}$ in the liver, and also increased the number of lymphocytes in broiler chickens.
\end{abstract}

Keywords: nanoparticle, chromium, mineral retention, immune response, broilers

\section{Introduction}

Chromium is an essential mineral element for humans and domestic animals (Lukaski, 1999). Trivalent chromium ( $\mathrm{Cr}$ (III)) is associated with the metabolism of carbohydrates, lipids, and proteins in animals, it also term the "glucose tolerance factor (GTF)", since chromium regulates the metabolic action of insulin (Schwarz \& Mertz, 1957). Wang and $\mathrm{Xu}$ (2004) suggested that the absorption and utilization of Cr may be dependent on its status in the intestinal tract. However, different $\mathrm{Cr}$ (III) forms have diverse rates of absorption. Organic $\mathrm{Cr}$ (III) has greater biological availability (utilization ability of animal) than inorganic Cr (III) (NRC, 1997; Lukaski, 1999). Inorganic $\mathrm{Cr}\left(\mathrm{e} . \mathrm{g} . \mathrm{CrCl}_{3}\right)$ is very low, in the range of 0.5-2\% (Mertz, 1969); organic $\mathrm{Cr}$ (e.g., $\left.\mathrm{CrPic}\right)$ is better, in the range of 10-25\% (Seerley, 1993).

In poultry, supplemental dietary CrPic resulted in an increase in egg production and improvements in the feed conversion ratio (Sahin et al., 2001; Yildiz et al., 2004). Moreover, organic Cr supplementation, particularly at $1200 \mathrm{ppb}$, increased the performance criteria, egg quality, and serum insulin concentrations of Japanese quails (Sahin et al., 2002). CrPic supplementation did not affect the body weight, feed consumption, or feed conversion ratio of broilers during 1-21 days, but the mortality rate of broilers was reduced and breast meat yield improved with supplemental $\mathrm{Cr}$ at either 300 or $400 \mathrm{ppb}$ (Hossain et al., 1998). However, Ward et al. (1993) reported that organic $\mathrm{Cr}$ supplementation at 200 and $400 \mathrm{ppb} \mathrm{Cr}$ did not affect weight gain, feed intake, feed conversion ratio, nitrogen retention, or muscle crude protein and ether extract content of broilers at three weeks of age.

Immunological function has been enhanced by $\mathrm{Cr}$ (III), and its effects seem more pronounced during stress (Borgs \& Mallard, 1998). Increasing in immune responses by $\mathrm{Cr}$ supplementation has been observed in broilers (Luo et al., 1999). Notably, most poultry diets are basically composed of plant origin ingredients, corn-soybean base diet, which have usually low content of chromium (Giri et al., 1990). 
Nanotechnology is a multidisciplinary scientific undertaking involving the nature of the polymer, zeta potential, and vehicle. Nanoparticles, which involves at least one dimension reduced to a nano-metric scale, exhibits new electrical, magnetic, mechanical, and biological properties (Gref et al., 1994), and have been identified as critical factors influencing particle uptake (Delie, 1998). Therefore, the new phenomena and properties of nanoparticles may have unique potential applications. In previous work, chromium nanoparticles have been shown to produce beneficial effects on growth performance, body composition, as well as increased tissue concentrations of $\mathrm{Cr}$ in selected muscles (Wang \& Xu, 2004). They have also been shown to enhance $\mathrm{Cr}$ digestibility and absorption in rats when supplemented with $200 \mathrm{ppb}$ NanoCr as well as exhibiting the ability to alter some blood metabolite concentrations (Zha et al., 2007; Lien et al., 2009). Wang and Xu (2004) found that the supplemented $200 \mathrm{ppb}$ nanoparticles chromium were able to produce beneficial effects on carcass characteristics, pork quality, and individual skeletal muscle weight. Results showed an approximate two- to three-fold higher tissue chromium deposition in selected muscle and organs compared to the control group, which implicated higher absorption and bioavailability of nanoparticles chromium. The toxicity study indicated that NanoCrpic at $1000 \mathrm{ppb}$ in vivo and at $300 \mathrm{ppb}$ in vitro shows no signs of toxicity to rats (unpublished data).

It is well known that a mineral intake at high levels will have antagonist effects on the other minerals. The knowledge pertaining to this antagonist in $\mathrm{Cr}$ still is in its infant stage. Iron-binding proteins are involved in chromium binding, transport, and storage (Feng et al., 2003). $\mathrm{CaCO}_{3}$ reduces $\mathrm{Cr}$ uptake and retention in rats (Seaborn \& Stoecker, 1990). It has also been reported that in stressed animal losses of zinc, copper, iron, and manganese were reduced by supplemental chromium (Sahin \& Sahin, 2002a; Schrauzer et al., 1986). On the other hand, Sahin and Sahin (2002) reported that the utilization of nitrogen and $\mathrm{Ca}, \mathrm{P}, \mathrm{Zn}$, and Fe is improved with supplemental chromium and ascorbic acid.

Our hypothesis is that the nanoparticles chromium may also have an antagonist effect on other minerals utilization and excretion, and consequently influence the animal growth performance and immune function. Therefore, this study was designed to compare the effects of dietary supplementation of nanoparticles of chromium picolinate on growth performance, mineral retention, and the immune responses of broiler chickens.

\section{Materials and Methods}

\subsection{Nanoparticles Size of Chromium Picolinate Determination}

The powder NanoCrPic was supplied by the Industrial technology research institute of Taiwan (Shintsu, Taiwan). The NanoCrPic size was measured by TEM (Figure 1). The average particle size of NanoCrPic was $80.8 \pm 2.7$ nm.

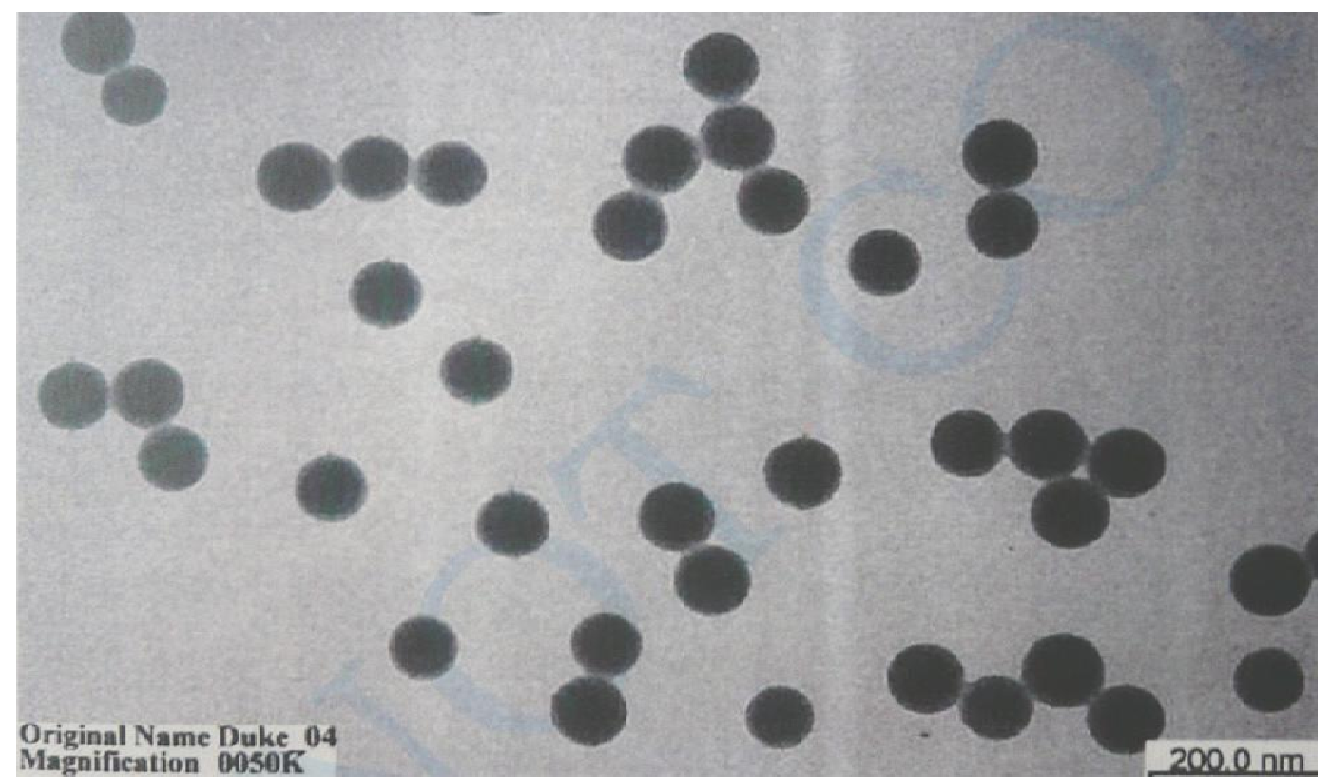

Figure 1. The image of nanoCr particles measured by TEM. Average

particle size of NanoCrPic was $80.8 \pm 2.7 \mathrm{~nm}$. 


\subsection{Experimental Design}

Table 1. The basal diet composition of broiler chicken

\begin{tabular}{|c|c|c|}
\hline \multirow{2}{*}{ Ingredients } & starter (0-3wks) & grower (4-5wks) \\
\hline & \multicolumn{2}{|c|}{------------_\%------------ } \\
\hline Yellow Corn & 41.59 & 47.81 \\
\hline Soybean meal & 22.5 & 12.5 \\
\hline DDGS $^{1}$ & 5.0 & 10.0 \\
\hline Full fat soybean meal & 17.5 & 15.0 \\
\hline Soybean oil & 3.0 & 2.0 \\
\hline Lard oil & 2.0 & 2.0 \\
\hline Fish meal & 2.5 & 2.5 \\
\hline Wheat middling & 2.5 & 5.0 \\
\hline Dicalcium phosphate (18\%) & 1.2 & 1.1 \\
\hline Limestone (35\%) & 1.4 & 1.3 \\
\hline Sodium chloride & 0.3 & 0.3 \\
\hline DL-Methionine & 0.2 & 0.15 \\
\hline Vitamin premix $^{2}$ & 0.15 & 0.13 \\
\hline Mineral premix ${ }^{3}$ & 0.15 & 0.13 \\
\hline Total & 100 & 100 \\
\hline \multicolumn{3}{|l|}{ Calculated value } \\
\hline Crude protein (\%) & 23.00 & 20.00 \\
\hline $\mathrm{ME}\left(\mathrm{MJ} \mathrm{kg}^{-1}\right)$ & 13.24 & 13.26 \\
\hline Calcium (\%) & 1 & 0.90 \\
\hline Available phosphorus (\%) & 0.45 & 0.35 \\
\hline Copper (mg) & 8 & 6 \\
\hline Zinc (mg) & 40 & 44 \\
\hline \multicolumn{3}{|l|}{ Analysis value } \\
\hline Crude protein (\%) & 22.36 & 20.04 \\
\hline Chromium (ppb) & 747.26 & 715.6 \\
\hline
\end{tabular}

${ }^{1}$ DDGS : Distiller's dried grains with soluble.

${ }^{2}$ Vitamin premix supplied per kilogram contain: retinol 12,500 IU; cholecalciferol 25,000 ICU; DL- $\alpha$ tocopheryl acetate 2,000 IU; menadione $250 \mathrm{mg}$; thiamine $200 \mathrm{mg}$; pyridoxine $300 \mathrm{mg}$; cyanocobalamin $12 \mathrm{mg}$; pantothenate $120 \mathrm{mg}$; niacin $350 \mathrm{mg}$; biotin $200 \mu \mathrm{g}$; folic acid $100 \mathrm{mg}$.

${ }^{3}$ Mineral premix supplied per kilogram contain: $\mathrm{Fe}\left(\mathrm{Fe}_{2}\left(\mathrm{SO}_{4}\right)_{3}\right) 153 \mathrm{mg} ; \mathrm{Mn}\left(\mathrm{MnSO}_{4}\right) 200 \mathrm{mg} ; \mathrm{Cu}$ $\left(\mathrm{CuSO}_{4}\right) 17.64 \mathrm{mg} ; \mathrm{Zn}(\mathrm{ZnO}) 105.8 \mathrm{mg} ; \mathrm{Mg}\left(\mathrm{MgSO}_{4}\right) 25.3 \mathrm{mg}$; Co $\left(\mathrm{Co} \mathrm{SO}_{4}\right) 0.4 \mathrm{mg}$; I (KI) $0.057 \mathrm{mg}$; Se $\left(\mathrm{Na}_{2} \mathrm{SeO}_{3}\right) 0.25 \mathrm{mg}$.

One hundred and eighty (Arbor Acres) one day-old broiler chickens (equal numbers of each sex) were randomly divided into three groups with six replicates (10 birds/pen) (experiment unit). The three groups used in the present study consisted of the following: (1) basal diet (Table 1) (control group), was formulated based on NRC (1994); (2) basal diet supplemented with $500 \mathrm{ppb}\left(\mu \mathrm{g} \mathrm{kg}^{-1}\right) \mathrm{Cr}$, i.e., nanoparticles of $\mathrm{CrPic}$ (NanoCrPic); (3) basal diet supplemented with $3000 \mathrm{ppb}$ NanoCrPic for a 35 day trial with the trial period divided into two stages, namely, the starter period ( $0-3$ weeks) and the growth period (4-5 weeks). Birds were floor-fed (width and length of each treatment: $160 \mathrm{~cm} \times 330 \mathrm{~cm}$ ). All birds were provided with uniform floors, electric lamps, feeders and gutters. 
Additionally, blood samples from 5 random birds per pen were taken for analysis at 14, 21 and 35 day intervals during the experiment. At the final of the experiment, 12 broilers ( 2 birds/pen) (pen is experiment unit) in each group were euthanized for carcass traits determine and liver samples were taken for mineral analysis. The average room temperature was $28.2 \pm 2.5^{\circ} \mathrm{C}$ and humidity was $71 \pm 5.5 \%$. A continuous lighting program was provided during the experiment. The animals were reared according to the Guide for the Care and Use of Agricultural Animals in Agricultural Research and Teaching, and this study was approved by the University's Animal Care and Use Committee.

One day old chicks were inoculated for Newcastle disease + infectious bronchitis (ND + IB). B1 strains were inoculated at seven days and the ND inactive vaccine was injected on the $28^{\text {th }}$ day of the experiment.

\subsection{Metabolic Trial}

Thirty-six chickens were chosen (the average weight about $1.5 \mathrm{~kg}$ ) at the day of 35, with 6 birds per group (three males and three females) in duplicates ( 2 birds/pen) (pen is the experiment unit) randomly assigned to three dietary groups. The individual cages were $90 \mathrm{~cm} \times 60 \mathrm{~cm} \times 60 \mathrm{~cm}$ with a plastic bag for collecting of total excreta. Birds were adapted for 7 days. The metabolic trial was lasting five days (on day 43-47). The total amount of food consumed (about $125 \mathrm{~g} \mathrm{day}^{-1}$ bird $^{-1}$ ) and excreta voided from each chicken was recorded (dry matter basis) and sampling for components analysis. Mineral retention ratio was calculated using the following equation:

$$
\text { Mineral retention ratio }=\frac{(W F I \times E F)-(W E V \times E E)}{(W F I \times E F)} \times 100
$$

WFI=weight of feed intake $(125 \mathrm{~g})$

$\mathrm{EF}=$ concentration of element in feed

WEV=weight of total excreta voided

$\mathrm{EE}=$ concentration of element in total excreta

\subsection{Determination Traits}

At 1,21 , and 35 days of age, individual body weight and feed consumed were recorded to calculate feed conversion ratios (feed/gain).

\subsection{Basal Diet Components Analysis}

Basal diet components of crude protein (CP: No. 7.015) were analyzed according the method of AOAC (2000). Gross energy using bomb calorimeter (Parr instrument company's, Illinois, USA) to measure.

\subsection{Blood Traits Determination}

Chickens were euthanized by severing the jugular vein; the blood sample (about $10 \mathrm{~mL}$ ) was collected, after coagulation then centrifugation $(1500 \times \mathrm{g}, 15 \mathrm{~min})$, the serum was obtained and stored at $-40^{\circ} \mathrm{C}$ for hematological analysis.

Newcastle disease antibody titer (ND antibody titer) determined in duplicates were followed the method described by Giambrone (1981) with a hemagglutination inhibition (HI) procedure after the $35^{\text {th }}$ day of the experiment.

Chickens blood was collected in a tube containing EDTA to prevent coagulation. Based on Campbell (1995), a small drop of blood was smeared on a slide and rapidly air dried. The smear slide was examined at $1000 \times$ magnification under oil immersion to count leucocytes up to a total of 100 cells, including basophils, eosinophils, lymphocytes, heterophils, and monocytes.

\subsection{Chromium Analysis}

Chromium analysis was base on the method of Anderson et al. (1985). Weighting $0.2 \mathrm{~g}$ of ground feed and excreta, and liver of each pen samples in duplicates were placed into crystal beakers, in which $10 \mathrm{~mL}$ of $70 \%$ nitric acid was added and rested for $8 \mathrm{~h}$ before beginning heat digestion (about $80^{\circ} \mathrm{C}$ ) for $8 \mathrm{~h}$. The samples were allowed to cool at which point the samples were diluted with $50 \mathrm{~mL}$ of de-ionized water. The filtered solution was kept in a polypolene bottle. Then, chromium was analyzed using a polarized Zeeman atomic absorption spectrometer (Hitachi, Japan) equipped with a graphite furnace, the analysis was done in duplicates. 


\subsection{Copper, Zinc, Manganese, and Iron Analysis}

According to AOAC (2000) methodology (No. 2.109), the steps are as follows: Weighting $1 \mathrm{~g}$ of feed, excreta, and liver of each pen samples in duplicates were crushed under a crucible. Following this, samples were subjected to $550^{\circ} \mathrm{C}$ for $5 \mathrm{~h}$ in a furnace to be converted to ash. The crucible was subjected to $10 \mathrm{~mL} 3 \mathrm{~N} \mathrm{HCl}$ under a heating plate and heated until the solution became clear. It was then allowed to cool (filtration quantitative to $50 \mathrm{~mL}$ with $0.1 \mathrm{~N} \mathrm{HCl}$ ). An atomic absorption spectrometer (Perkin Elmer, Atomic Analyst 100, USA) was used to analyze the copper, zinc, manganese and iron contents.

\subsection{Calcium and Phosphorous Analysis}

According AOAC (2000) methodology (Ca: No. 7.096, P: No. 7.119), the steps are as follows: weighting $1 \mathrm{~g}$ of feed, excreta, and liver of each pen samples in duplicates were crushed under a crucible. Following this, samples were subjected to $550^{\circ} \mathrm{C}$ for $5 \mathrm{~h}$ in a furnace to be converted to ash. The crucible was subjected to $10 \mathrm{~mL} 3 \mathrm{~N} \mathrm{HCl}$ under a heating plate and heated until the solution became clear. It was then allowed to cool (filtration quantitative to $50 \mathrm{~mL}$ with $0.1 \mathrm{~N} \mathrm{HCl}$ ).

Calcium content analysis was undertaken by adding lanthanum $185.4 \mu \mathrm{L}$ at $50,000 \mathrm{ppm}$ to $6 \mathrm{~mL}$ samples solution. Then, an atomic absorption spectrometer (Perkin Elmer, Atomic Analyst 100, USA) was used for analysis.

For phosphorous determination, a $1 \mathrm{~mL}$ sample plus $1 \mathrm{~mL}$ Vanadium-molybenum acid and $3 \mathrm{~mL}$ de-ionized water (to a total of $5 \mathrm{~mL}$ ) was left standing for 10 minutes and an automatic scanning sub-ray spectrometer (Beckman, DRR 640i, USA) was employed, with the wavelength set at $400 \mathrm{~nm}$.

\subsection{Statistical Analysis}

The experiment data were subjected to statistical analysis using SAS software (version 9.1, SAS 1998). The general linear model procedure (GLM) was used based on the completely randomized design (CRD). Tukey's tests were adopted in the model to determine the P values among the variables. According to the following model, treatment $(\mathrm{T})$ was the main effect.

$$
Y=\mu+T_{i}+P_{j}+e_{i j k}
$$

Where $Y$ is the dependent variable, $\mu$ represents the mean, $\mathrm{P}$ is the pen (replicate, experiment unit) effect and e is the random residual error term. The level of significantly different was set at $\mathrm{p}<0.05$.

\section{Results and Discussion}

\subsection{The Effects of Different Levels of NanoCrpic on the Growth Performance of Broiler Chickens}

The effects of dietary NanoCrPic supplementation on broiler chickens performance are shown in Table 2. This table demonstrates that a significant improvement in the feed conversion ratio (FCR) in $3000 \mathrm{ppb}$ NanoCrPic group during 1-21 days of age was observed as compared to the control group $(\mathrm{p}=0.05)$. However, the average feed intake (AFI) was significantly decreased $(\mathrm{p}<0.05)$ by the $3000 \mathrm{ppb}$ NanoCrPic supplementation in the period of 1-21 days and 22-35 days, as well as the 500 ppb groups in the period of 1-35 days. However, average body weight gain (ABWG) and body weight (BW) were insignificantly different with NanoCrPic supplementation.

Previous studies showed that the Cr supplementation at 0, 200, and $400 \mathrm{ppb}$ had little or no effect on feed intake and feed efficiency in broiler chickens at six weeks of age (Motozono et al., 1998). Similarly, Anandhi et al. (2006) reported the same conclusions on the inclusion of chromium in their diet. Moreover, CrPic supplementation did not affect the body weight, feed consumption, or feed conversion ratio of broilers during 1-21 days, the mortality rate was reduced, and breast meat yield was improved with supplemental $\mathrm{Cr}$ at $300 \mathrm{or} 400 \mathrm{ppb}$ levels (Hossain et al., 1998). On the other hand, Sahin et al. (2002) reported that increased supplemental chromium (200, 400, 800, or $1200 \mathrm{ppb}$ CrPic) resulted in an increase in body weight, feed intake, and feed efficiency in broilers reared under heat stress. In addition, Sahin et al. (2003) found the decrease in live weight gain and feed efficiency in broilers reared under heat stress was alleviated by dietary chromium and vitamin $\mathrm{C}$ supplementation.

The carcass characteristics of broiler chickens, namely carcass yield, percentage of dressing, relative liver, spleen, and thigh weight were not affected by the dietary groups (Table 3). Increased carcass yield in broilers has been reported for diets supplemented with CrPic (Sahin et al., 2002b 2003; Saikat et al., 2008). It is well known that $\mathrm{Cr}$ is involved in protein metabolism (Anderson, 1987). Also, Cr plays an important role as an integral component of the glucose tolerance factor (GTF), which potentiates the action of insulin and regulates glucose metabolism (Mertz, 1969). However, in this study no effects on carcass characteristics were observed during NanoCrPic supplementation, except that carcass weight was slightly lower in $3000 \mathrm{ppb}$ group than control group $(\mathrm{p}<0.1)$. 
Table 2. The effect of different level of nano-chromium on performance of broilers

\begin{tabular}{cccccc}
\hline \multirow{5}{*}{ Age [days] Supplemented dietary NanoCrPic (ppb) } & SEM P value \\
\cline { 2 - 6 } & 0 & 500 & 3000 & \\
\hline \multicolumn{5}{c}{ Body weight $(\mathrm{g})(\mathrm{BW})$} \\
21 & 34.00 & 34.00 & 34.00 & 0.33 & 0.58 \\
35 & 749.0 & 710.0 & 688.0 & 16.0 & 0.11 \\
\multicolumn{7}{c}{1901} & 1851 & 1788 & 56.9 & 0.33 \\
$1-21$ & 715.0 & 675.0 & 654.0 & 15.3 & 0.10 \\
$22-35$ & 1152 & 1140 & 1100 & 27.5 & 0.62 \\
$1-35$ & 1867 & 1817 & 1754 & 56.8 & 0.28 \\
$1-21$ & $1113^{\mathrm{a}}$ & $1014^{\text {ab }}$ & $939^{\mathrm{b}}$ & 12.3 & 0.01 \\
$22-35$ & 2398 & 2279 & 2223 & 36.9 & 0.13 \\
$1-35$ & $3503^{\mathrm{a}}$ & $3294^{\mathrm{b}}$ & $3162^{\mathrm{b}}$ & 42.3 & 0.01 \\
$1-21$ & $1.56^{\mathrm{a}}$ & $1.50^{\mathrm{ab}}$ & $1.44^{\mathrm{b}}$ & 0.02 & 0.01 \\
$22-35$ & 2.08 & 2.01 & 2.03 & 0.11 & 0.78 \\
$1-35$ & 1.88 & 1.81 & 1.80 & 0.08 & 0.36 \\
\hline
\end{tabular}

${ }^{a, b}$ Means within the same row without the same superscripts differ significantly $(\mathrm{p}<0.05)$.

SEM: standard error of mean.

${ }^{*}=6(10$ birds/pen).

Table 3. Effect of different level of nano-chromium on carcass characteristics and meat quality of 35 day-old broilers

\begin{tabular}{lccccc}
\hline \multirow{2}{*}{ Item } & \multicolumn{2}{c}{ Supplemented dietary NanoCrPic $(\mathrm{ppb})$} & \multirow{2}{*}{ SEM } & \multirow{2}{*}{ P value } \\
\cline { 2 - 4 } & 0 & 500 & 3000 & & \\
\hline Carcass weight $(\mathrm{g})$ & 1526 & 1488 & 1442 & 52.6 & 0.08 \\
Dressing percentage (\%) & 80.3 & 80.4 & 80.4 & 0.55 & 0.97 \\
Liver $\left({\left.\mathrm{g} 100 \mathrm{~g} \mathrm{BW}^{-1}\right)}^{3.03}\right.$ & 2.79 & 2.74 & 0.15 & 0.23 \\
Spleen $\left({\left.\mathrm{g} 100 \mathrm{~g} \mathrm{BW}^{-1}\right)}^{0.18}\right.$ & 0.19 & 0.17 & 0.02 & 0.81 \\
Thigh $\left({\left.\mathrm{g} 100 \mathrm{~g} \mathrm{BW}^{-1}\right)}^{27.1}\right.$ & 28.7 & 27.3 & 1.96 & 0.81 \\
\hline
\end{tabular}

${ }^{a, b}$ Means within the same row without the same superscripts different significantly $(\mathrm{p}<0.05)$;

SEM: standard error of mean;

${ }^{*} \mathrm{n}=6(2$ birds/pen).

\subsection{The Effects of Different Levels of NanoCrPic on the Minerals Retention Ratio in Broiler Chickens}

Chromium and other minerals, namely $\mathrm{Cu}, \mathrm{Zn}, \mathrm{Fe}, \mathrm{Mn}, \mathrm{Ca}$ and $\mathrm{P}$ retention ratio in the broilers are shown in Table 4. The mineral retention ratio of $\mathrm{Cr}(\mathrm{p}<0.0001), \mathrm{Zn}(\mathrm{p}<0.0001), \mathrm{Fe}(\mathrm{p}=0.008), \mathrm{Mn}(\mathrm{p}=0.01), \mathrm{Ca}(\mathrm{p}<0.0001)$ and $\mathrm{P}$ $(\mathrm{p}=0.01)$ were increased through NanoCrPic supplementation. However, retention of $\mathrm{Cu}$ was not affected by dietary treatments.

Amatya et al. (2004) reported that supplemental $\mathrm{Cr}$ had effect on the intake and retention of trace minerals $(\mathrm{Cu}, \mathrm{Zn}$, $\mathrm{Fe}$, and $\mathrm{Mn}$ ) in broilers. El-Husseiny and Creger (1981) also found that broilers reared under environmental stress had lower rates of $\mathrm{Ca}, \mathrm{Cu}, \mathrm{Fe}, \mathrm{K}, \mathrm{Mg}, \mathrm{Mn}, \mathrm{Na}, \mathrm{P}$, and $\mathrm{Zn}$ retention. Notably, stress increases chromium 
mobilization from tissues and its excretion (Borel et al., 1984; Anderson, 1987). The retention of Ca and $\mathrm{P}$ among the $\mathrm{Cr}$ supplemented groups was varied; the $500 \mathrm{ppb}$ group was better than the $3000 \mathrm{ppb}$ group.

Table 4. The effect of different levels of nano-chromium on minerals retention ratio of broiler chickens

\begin{tabular}{lccccc}
\hline \multirow{2}{*}{ Items (\%) } & \multicolumn{2}{c}{ Supplemented dietary NanoCrPic (ppb) } & \multirow{2}{*}{ SEM } & \multirow{2}{*}{ P value } \\
\cline { 2 - 4 } & 0 & 500 & 3000 & & \\
\hline $\mathrm{Cr}$ & $3.72^{\mathrm{b}}$ & $19.86^{\mathrm{a}}$ & $24.03^{\mathrm{a}}$ & 2.79 & 0.0001 \\
$\mathrm{Cu}$ & 24.77 & 32.01 & 28.42 & 3.03 & 0.83 \\
$\mathrm{Zn}$ & $51.48^{\mathrm{b}}$ & $66.83^{\mathrm{a}}$ & $67.42^{\mathrm{a}}$ & 0.50 & 0.0001 \\
$\mathrm{Fe}$ & $51.88^{\mathrm{b}}$ & $60.91^{\mathrm{a}}$ & $57.72^{\mathrm{a}}$ & 1.16 & 0.008 \\
$\mathrm{Mn}$ & $35.87^{\mathrm{b}}$ & $48.69^{\mathrm{a}}$ & $40.68^{\mathrm{b}}$ & 1.12 & 0.01 \\
$\mathrm{Ca}$ & $42.59^{\mathrm{c}}$ & $60.11^{\mathrm{a}}$ & $48.84^{\mathrm{b}}$ & 0.68 & 0.0001 \\
$\mathrm{P}$ & $24.12^{\mathrm{b}}$ & $29.94^{\mathrm{a}}$ & $26.25^{\mathrm{b}}$ & 0.90 & 0.01 \\
\hline
\end{tabular}

a,b,c Means within a row with no common superscripts are significantly different $(\mathrm{p}<0.05)$;

SEM: standard error of mean;

Mineral retention ratio $=($ intake - excreta $) \div$ intake $\times 100 \%$;

$\mathrm{n}=6(2$ birds/pen $)$.

\subsection{The Effects of Different Levels of NanoCrPic on the Liver Minerals Retention in Broiler Chickens}

The effects of dietary NanoCrPic supplementation on liver minerals are shown in Table 5. This table demonstrates that a significant accumulation of chromium in the liver $(\mathrm{p}=0.0002)$, as well as the phosphorus $(\mathrm{p}<0.0001)$ and calcium ( $\mathrm{p}<0.0001$ ) of NanoCrPic groups were observed as compared to the control group. $\mathrm{Cu}, \mathrm{Zn}, \mathrm{Fe}$, and $\mathrm{Mn}$ were not affected by NanoCrPic supplementation.

Previous research studies indicated that $\mathrm{Cr}$ supplementation offers protection against stress-induced losses of $\mathrm{Zn}$, $\mathrm{Fe}$ and $\mathrm{Mn}$ in liver and heart tissues (Schrauzer et al., 1986). Increased tissue concentrations of $\mathrm{Cr}$, as observed in the present study, would have such phenomena. Amatya et al. (2004) reported that the concentration of copper, iron and zinc in the liver were increased while manganese was not affected by dietary chromium in broiler chickens. Increasing dietary chromium supplementation increased liver chromium and zinc concentrations, whereas copper concentrations decreased and liver iron concentrations were not affected in Japanese quails (Sahin et al., 2002). Those reports are in agreement with our results. The results of this study indicate that chromium is accumulated in liver.

Table 5. The effect of different level of nano-chromium on liver minerals content of broiler chickens

\begin{tabular}{|c|c|c|c|c|c|}
\hline \multirow{2}{*}{ Items } & \multicolumn{3}{|c|}{ Supplemented dietary NanoCrPic (ppb) } & \multirow{2}{*}{ SEM } & \multirow{2}{*}{$P$ value } \\
\hline & 0 & 500 & 3000 & & \\
\hline $\mathrm{Cr}\left(\mu \mathrm{g} \mathrm{kg}^{-1}\right)$ & $300^{6}$ & $563^{\mathrm{a}}$ & $670^{\mathrm{a}}$ & 36.3 & 0.0002 \\
\hline $\mathrm{Cu}\left(\mathrm{mg} \mathrm{kg}^{-1}\right)$ & 6.59 & 7.48 & 7.12 & 0.66 & 0.63 \\
\hline $\mathrm{Zn}\left(\mathrm{mg} \mathrm{kg}^{-1}\right)$ & 46.4 & 56.3 & 56.8 & 4.57 & 0.23 \\
\hline $\mathrm{Fe}\left(\mathrm{mg} \mathrm{kg}^{-1}\right)$ & 179 & 185 & 193 & 11.8 & 0.69 \\
\hline $\operatorname{Mn}\left(\mathrm{mg} \mathrm{kg}^{-1}\right)$ & 3.16 & 3.05 & 3.06 & 0.28 & 0.96 \\
\hline $\mathrm{Ca}(\%)$ & $0.015^{\mathrm{b}}$ & $0.024^{\mathrm{a}}$ & $0.025^{\mathrm{a}}$ & 0.001 & 0.0001 \\
\hline $\mathrm{P}(\%)$ & $0.132^{\mathrm{b}}$ & $0.221^{\mathrm{a}}$ & $0.218^{\mathrm{a}}$ & 0.005 & 0.0001 \\
\hline
\end{tabular}

${ }^{a, b}$ Means within a row with no common superscripts are significantly different $(\mathrm{p}<0.05)$.

SEM: standard error of mean.

${ }^{*} \mathrm{n}=6(2$ birds/pen $)$.

\subsection{The Effects of Different Levels of NanoCrpic on Immune Responses in Broiler Chickens}

The effects of supplemental dietary NanoCrPic on hematological parameters at the $35^{\text {th }}$ day of the experiment is shown in Table 6. Statistical analysis revealed no significant difference in white blood cells (WBC) and WBC sub-groups, namely basophils, eosinophils, and monocytes. On the other hand, lymphocytes significantly 
increased ( $\mathrm{p}=0.0004$ ) in chicken fed $3000 \mathrm{ppb}$ NanoCrPic, whereas heterophils and heterophil to lymphocyte ratio were significantly decreased in both 500 and $3000 \mathrm{ppb}$ NanoCrPic groups $(\mathrm{p}<0.05)$. The results were agreement with those of Zha et al. (2008) who found that dietary supplementation of 150,300, and $450 \mathrm{ppb} \mathrm{Cr}$ from NanoCr enhanced the lymphoproliferative response in Sprague-Dawley rats; Toghyani et al. (2007) also reported increases in lymphocyte counts and decreases in heterophil to lymphocyte ratios in 1000 and $1500 \mathrm{ppb} \mathrm{CrPic}$ supplementation in heat-stressed chicks.

The number of heterophils increased in the blood of corticosterone (stress) fed chicks (Gross \& Siegel, 1983). The heterophil to lymphocyte $(\mathrm{H} / \mathrm{L})$ ratio was used as an index of chronic stress (Bonier et al., 2007), based on the observation that increased glucocorticoid secretion may result of lymphocytopenia and a subsequent increase in heterophil numbers (Harmon, 1998). Moreover, the H/L ratio increases in response to a variety of stressors including malnutrition, water deprivation, and injury (Gross \& Siegel, 1983; Vleck, 2000). Thus, the results of this study indicated that NanoCrPic supplementation exhibits an anti-stress function.

Table 6. The effect of different level of nano-chromium on concentration and subgroup ratio of white blood cells (WBCs) parameter in 35 days old broiler chickens

\begin{tabular}{cccccc}
\hline \multirow{2}{*}{ Hematological parameters } & \multicolumn{2}{c}{ Supplemented dietary NanoCrPic (ppb) } & \multirow{2}{*}{ SEM } & \multirow{2}{*}{ P value } \\
\cline { 2 - 4 } & 0 & 500 & 3000 & & \\
\hline WBC count $\left(10^{5}\right.$ cells $\left./ \mathrm{mm}^{\mathrm{s}}\right)$ & 27.6 & 24.8 & 25.7 & & 0.46 \\
WBC sub group $(\%)$ & & & & & \\
Basophils & 12.5 & 11.0 & 12.2 & 0.84 & 0.43 \\
Eosinophils & 2.25 & 2.08 & 2.30 & 0.34 & 0.89 \\
Lymphocytes & $45.1^{\mathrm{b}}$ & $50.6^{\mathrm{b}}$ & $58.6^{\mathrm{a}}$ & 1.83 & 0.0004 \\
Heterophils & $27.5^{\mathrm{a}}$ & $23.9^{\mathrm{b}}$ & $23.8^{\mathrm{b}}$ & 0.53 & 0.002 \\
Monocytes & 7.92 & 9.00 & 9.50 & 1.28 & 0.68 \\
H/L ratio & $0.61^{\mathrm{a}}$ & $0.47^{\mathrm{b}}$ & $0.41^{\mathrm{c}}$ & 0.02 & 0.0001 \\
\hline
\end{tabular}

a, ${ }^{2}$ Means within the same row without the same superscripts differ significantly $(\mathrm{p}<0.05)$;

SEM: standard error of mean;

$\mathrm{H} / \mathrm{L}$ : heterophils to lymphocyte ratio;

${ }^{*} \mathrm{n}=6(5$ birds/pen).

Dietary $3000 \mathrm{ppb}$ NanoCrPic group had significant $(\mathrm{p}=0.01)$ effects on Newcastle disease antibody titers at 21 days; while at 28 and 35 days, no affects were resultant by NanoCrPic supplementation (Table 7). The results are in agreement with those of Toghyani et al. (2007) who reported that the antibody titers against Newcastle and Influenza virus tended to increase in broiler chickens receiving $1000 \mathrm{ppb}$ and $1500 \mathrm{ppb}$ CrPic. Elevated antibody titers against Newcastle disease were reported in broiler chicks with supplemental 2 or $10 \mathrm{mg} / \mathrm{kg} \mathrm{Cr}$, either in the form of $\mathrm{CrCl}_{3}$ or Cr-yeast (Guo et al., 1999).

The role of chromium in the immune responses of mammals and chicken is well established (Burton et al., 1993; Lee et al., 2003). It has also been reported that chromium modulates the immune response through its effect on cytokine release (Wang et al., 1996).

Table 7. Effect of different level of nano-chromium on Newcastle disease antibody titer in broilers

\begin{tabular}{llllll}
\hline \multirow{2}{*}{ Age (day) } & \multicolumn{3}{c}{ Supplemented dietary NanoCrPic $(\mathrm{ppb})$} & \multirow{2}{*}{ SEM } & \multirow{2}{*}{ P value } \\
\cline { 2 - 4 } & 0 & 500 & 3000 & & \\
\hline \multirow{2}{*}{$\mathrm{ND}^{1}$ antibody titer $\left(\log _{2}\right)$} & & & & \\
28 & $2.72^{\mathrm{b}}$ & $2.85^{\mathrm{b}}$ & $3.54^{\mathrm{a}}$ & 0.18 & 0.01 \\
35 & 3.43 & 3.87 & 3.64 & 0.16 & 0.18 \\
\hline
\end{tabular}

${ }^{a, b}$ Means within a row with no common superscripts are significantly different $(\mathrm{p}<0.05)$.

SEM: standard error of mean.

${ }^{1} \mathrm{ND}$ : Newcastle disease.

${ }^{*} \mathrm{n}=6(5$ birds/pen $)$. 


\section{Conclusion}

This study found that NanoCrPic supplementation in chickens can improve utilization of $\mathrm{Zn}, \mathrm{Fe}, \mathrm{Ca}$ and decrease the $\mathrm{Zn}, \mathrm{Fe}, \mathrm{Ca}$ content of excreta, showing increased minerals $\mathrm{Cr}$, $\mathrm{Ca}$ concentration in the liver as well as in lymphocytes of broiler chickens.

\section{References}

A.O.A.C. (2000). Official Methods of Analysis (17th ed). Association of Official Analytical Chemist. Virginia, U.S.A.

Amatya, J. L., Haldart, S., \& Ghosh, T. K. (2004). Effects of chromium supplementation from inorganic and organic sources on nutrient utilization, mineral metabolism and meat quality in broiler chickens exposed to natural heat stress. Anim. Sci., 79, 241-253.

Anandhi, M., Mathivanan, R., Viswanathan, K., \& Mohan, B. (2006). Dietary inclusion of organic chromium on production and carcass characteristics of broilers. Int. J. Poult. Sci., 5, 880-884. http://dx.doi.org/10.3923/ijps.2006.880.884

Anderson, R. A. (1987). Chromium: Trace Elements in Human and Animal nutrition (pp. 225-244). New York: Academic Press.

Anderson, R. A., \& Kozlovsky, A. S. (1985). Chromium intake, absorption and excretion of subjects consuming self-selected diets. Am. J. Clin. Nutr., 41, 1177-1183.

Bonier, F., Martin, P. R., Sheldon, K. S., Jensen, J. P., Foltz, S. L., \& Wing Field, J. C. (2007). Sex-specific consequences of life in the city. Behav. Ecology, 18, 121-129. http://dx.doi.org/10.1093/beheco/arl050

Borel, J. S., Majeres, T. C., Polansky, M., Moser, P. B., \& Anderson, R. A. (1984). Chromium intake and urinary chromium excretion of trauma patients. Biolog. Trace Elem. Res. (Abstr.).

Borgs, P., \& Mallard, B. A. (1998). Immune-endocrine interactions in agricultural species: Chromium and its effect on health and performance. Domes. Anim. Endoc., 15, 431-438. http://dx.doi.org/10.1016/S0739-7240(98)00018-6

Burton, J. L., Mallard, B. A., \& Mowat, D. N. (1993). Effects of supplemental chromium on immune responses of periparturient and early lactation dairy cows. J. Anim. Sci., 71, 1532-1539.

Campbell, T. W. (1995). Avian Hematology and Cytology (p. 108). Ames: IowaState University Press.

Delie, F. (1998). Evaluation of nano-and microparticle uptake by the gastrointestinal tract. Adv. Drug Deliv. Rev., 34, 221-233. http://dx.doi.org/10.1016/S0169-409X(98)00041-6

El-Husseiny, O., \& Creger, C. R. (1981). Effect of ambient temperature on mineral retention and balance of the broiler chicks. Poult. Sci., 60, 1651. (Abstr.).

Feng, W., Li, B., Liu, J., Chai, Z., Zhang, P., Gao, Y., \& Zhao, J. (2003). Study of chromium containing proteins in sub cellular fractions of rat liver by enriched stable isotopic tracer technique and gel filtration chromatography. Analyt. Bioanalyt. Chem., 375, 363-368.

Giambrone, J. J. (1981) Laboratory evaluation of the immune response of young broiler chickens vaccinated against Newcastle disease under field condition. Poult. Sci., 60, 1204-1208. http://dx.doi.org/10.3382/ps.0601204

Giri, J., Usha, K., \& Sunita, T. (1990). Evaluation of the selenium and chromium content of plant foods. Plant foods Human Nut., 40, 49-59.

Gref, R., Minamitake, Y. M., Peracchia, T., Trubetskoy, V., Torchilin, V., \& Langer, R. (1994). Biodegradable long-circulating polymeric nanospheres. Science, 263, 1600-1603. http://dx.doi.org/10.1126/science.8128245

Gross, W. B., \& Siegel, H. S. (1983). Evaluation of the heterophil/lymphocyte ratio as a measure of stress in chickens. Avian Dis., 27, 972-979. http://dx.doi.org/10.2307/1590198

Guo, Y. L., Luo, X. G., Hao, Z. L., Liu, B., Chen, J. L., Gao, F. S., \& Yu, S. X. (1999). Effect of chromium on growth performance, serum biochemical traits, immune function and carcass quality of broiler chickens. Sci. Agri. Sinica, 32, 79-86.

Harmon, B. G. (1998). Avian heterophils in inflammation and disease resistance. Poult. Sci., 77, 972-977. 
Hossain, S. M., Barreto, S. L., \& Silva, C. G. (1998). Growth performance and carcass composition of broilers fed supplemental chromium from chromium yeast. Anim. Feed Sci. Technol., 71, 217-228. http://dx.doi.org/10.1016/S0377-8401(97)00160-0

Lee, D. N., Wu, F. Y., Cheng, Y. H., Lin, R. S., \& Wu, P. C. (2003). Effect of dietary chromium picolinate supplementation on growth performance and immune responses of broilers. Asian-Aust. J. Anim. Sci., 16, 227-233.

Lien, T. F., Yeh, H. S., Lu, F. Y., \& Fu, C. M. (2009). Nanoparticles of chromium picolinate enhance chromium digestibility and absorption. J. Sci. Food Agric., 89, 1164-1167. http://dx.doi.org/10.1002/jsfa.3569

Lukaski, H. C. (1999). Chromium as a supplement. Annual Rev. Nutr., 19, 279-302. http://dx.doi.org/10.1146/annurev.nutr.19.1.279

Luo, X., Guo, Y. L., Liu, B., Hao, Z. L., Chen, J. L., Gao, F. S., \& Yu, S. X. (1999). Effect of dietary chromium on growth, serum biochemical traits and immune responses of broiler chicks during 0-3 weeks of age. Acta veterin. Et Zootech. Sinica, 30, 481-489.

Mertz, W. (1969). Chromium occurrence and function in biological systems. Physiol. Rev., 49, 163-239.

Motozono, Y., Hatano, K., Sugawara, N., \& Ishibashi, T. (1998). Effects of dietary chromium picolinate on growth, carcass quality and serum lipids of female broilers. Anim. Sci. Technol., 69, 659-665.

National Research Council. (1994). Nutrient requirements of poultry, ninth revised edition. Washington, D.C.: National Academy Press.

Sahin, K., \& Sahin, N. (2002). Effects of chromium picolinate and ascorbic acid dietary supplementation on nitrogen and mineral excretion of laying hens reared in low ambient temperature $\left(7^{\circ} \mathrm{C}\right)$. Acta Veterin. Brno, 71, 183-189. http://dx.doi.org/10.2754/avb200271020183

Sahin, K., Kucuk, O., \& Sahin, N. (2001). Effects of dietary chromium picolinate supplementation on performance and plasma concentrations of insulin and corticosterone in laying hens under low ambient

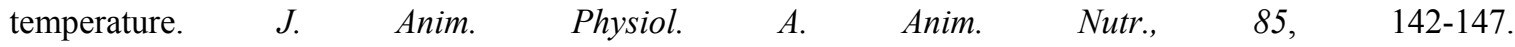
http://dx.doi.org/10.1046/j.1439-0396.2001.00314.x

Sahin, K., Sahin, N., \& Kucuk, O. (2002). Effects of dietary chromium picolinate supplementation on serum and tissue mineral contents of laying Japanese quails. J. Trace Elem. Exper. Med., 15, 163-169. http://dx.doi.org/10.1002/jtra.10013

Sahin, K., Sahin, N., \& Kucuk, O. (2003). Effects of chromium, and ascorbic acid supplementation on growth, carcass traits, serum metabolites and antioxidant status of broiler chickens reared at a high ambient temperature. Nutr. Res., 23, 225-238. http://dx.doi.org/10.1016/S0271-5317(02)00513-4

Saikat, S., Haldar, S., Bahadur, V., \& Ghosh, T. K. (2008). Chromium picolinate can ameliorate the negative effects of heat stress and enhance performance, carcass and meat traits in broiler chickens by reducing the circulatory cortisol level. J. Sci. Food Agri., 88, 787-796. http://dx.doi.org/10.1002/jsfa.3146

Schrauzer, G. N., Shrestha, K. P., Molenaar, T. B., \& Mead, S. (1986). Effects of chromium supplementation on food energy utilization and the trace-element composition in the liver and heart of glucose-exposed young mice. Biolog. Trace Elem. Res. (Abstr.).

Schwarz, K., \& Mertz, W. (1957). A glucose tolerance factor and its differentiation from factor 3. Arch. Biochem. Biophys., 72, 515-518. http://dx.doi.org/10.1016/0003-9861(57)90228-X

Seaborn, C. D., \& Stoecker, B. J. (1990). Effects of antacid or ascorbic acid on tissue accumulation and urinary excretion of ${ }^{51}$ chromium. Nutr. Res., 10, 1401-1407. http://dx.doi.org/10.1016/S0271-5317(05)80132-0

Seerley, R. W. (1993). Organic chromium and manganese in human nutrition: important possibilities for manipulating lean meat deposition in animals. Proceeding of Alltech's 9th Annual Symposium (pp. 41-51). KY, USA: Nicholasville.

Statistical Analysis System Institute Inc. (1998). SAS/STAT User's guide: statistics, Version 6.06, Cary, NC, USA: SAS Institute Inc.

Toghyani, M., Zarkesh, S., Shivazad, M., \& Gheisari, A. (2007). Immune responses of broiler chicks fed chromium picolinate in heat stress condition. J. Poult. Sci., 44, 330-334. http://dx.doi.org/10.2141/jpsa.44.330 
Vleck, C. M. (2000). Comparison of corticosterone and heterophil to lymphocyte ratios as indicators of stress in free-living birds. In: A. Dawson (ed.). Perspectives in avian endocrinology. India: Narosa Publ.

Wang, J. L., Tsukayama, D. T., Wicklund, B. H., \& Gustilo, R. B. (1996). Inhibition of T and B cell proliferation by titanium, cobalt and chromium: Role of IL-2 and IL-6. J. Biomed. Materi. Res., 32, 655-661. http://dx.doi.org/10.1002/(SICI)1097-4636(199612)32:4<655::AID-JBM19>3.0.CO;2-C

Wang, M. Q., \& Xu, Z. R. (2004). Effect of chromium nano-particle on growth performance, carcass characteristics, pork quality and tissue chromium in finishing pigs. Asian-Aust. J. Anim. Sci., 17, 1118-1122.

Ward, T. L., Southern, L. L., \& Boleman, S. L. (1993). Effect of dietary chromium picolinate on growth, nitrogen balance and body composition of growing broiler chicks. Poult. Sci., 72, 37-43.

Yildiz, A., Parlat, S., \& Yazgan, O. (2004). The effects of organic chromium supplementation on production traits and some serum parameters of laying hens. Revue de Méd. Véterin., 12, 642-646.

Zha, L., Zeng, J., Sun, S., Deng, H., Luo, H., \& Li, W. (2008). Chromium (III) nanoparticles affect hormone and immune responses in heat-stressed rats. Biolog. Trace Elem. Res., 129, 157-169. (Abstr.). http://dx.doi.org/10.1007/s12011-008-8282-9

Zha, L.Y., Xu, Z. R., Wang, M. Q., \& Gu, L. Y. (2007). Effects of chromium nanoparticles dosage on growth, body composition, serum hormones and tissue chromium in Sprague-Dawley rats. J. Zhejiang University Sci., $B(8), 323-330$. http://dx.doi.org/10.1631/jzus.2007.B0323 